\title{
Greening global product chains: bridging barriers in the north-south cooperation. An exploratory study of possibilities for improvement in the product chains of table grape and wine connecting South Africa and the Netherlands
}

\author{
P.J. Ras* \\ Center for Entrepreneurship \\ Tshwane University of Technology \\ Private Bag X 680, Pretoria, 0001, South Africa \\ E-mail: raspj@tut.ac.za \\ *Corresponding author
}

\section{W.J.V. Vermeulen}

Department of Environmental Studies and Policies

Copernicus Institute for Sustainable Development and Innovation

Utrecht University

P.O. Box 80115, NL - 3508 TC Utrecht, The Netherlands

E-mail: w.vermeulen@geo.uu.nl

\section{S.L. Saalmink}

Trifolia

P.O. Box 1383

3500 BJ Utrecht, The Netherlands

E-mail:stefan@trifolia.nl

\begin{abstract}
Few case studies of business-to-business cooperation in the greening of global product chains are available. Problems with market communication, power, information availability, anonymous markets and information costs prevent communication between producers and end-users in the North and supplying firms in developing countries. This article reports our study on product chains of fruits and wine connecting South Africa with the Netherlands. Activities exist in both countries for improving environmental performance without the knowledge of business partners at the other side of the product chain. Thus, opportunities for systematic worldwide greening of these product chains are being missed. Taking one exemplary case of greening product chains in the field of organic fruit, we examined trade partners' willingness to cooperate in greening their product chains and possible solutions to barriers for supplier-retailer-end-user cooperation in the case of wine and grapes.
\end{abstract}

Keywords: global trade; sustainable business; corporate social responsibility; supply chain management. 
Reference to this paper should be made as follows: Ras, P.J., Vermeulen, W.J.V. and Saalmink, S.L. (2007) 'Greening global product chains: bridging barriers in the north-south cooperation. An exploratory study of possibilities for improvement in the product chains of table grape and wine connecting South Africa and the Netherlands', Progress in Industrial Ecology - An International Journal, Vol. 4, No. 6, pp.401-417.

Biographical notes: Peter J. Ras is a Lecturer in the field of entrepreneurship at the Tshwane University of Technology, Faculty of Management, Centre of Entrepreneurship

Walter J.V. Vermeulen is an Associate Professor in the field of governance of sustainable production and consumption at the Department of Environmental Studies and Policies, Institute for Sustainable Development and Innovation, Utrecht University.

Stefan Saalmink studied environmental sciences at Utrecht University and addressed the issue reported in this article in his Master's thesis study. He now runs the consultancy firm Trifolia, specialising in the development of international learning networks for sustainable development.

\section{Introduction}

This article reports the results of a research project regarding sustainability in global product chains in specific agricultural product chains connecting South Africa and the Netherlands. In 1987, the Brundtland Commission (WCED) stressed the need to achieve intergenerational equality and to address the current inequality of global economic exchanges. They defined sustainable development as a development that meets the needs of the present without compromising the ability of future generations to meet their own needs (WCED, 1987). Since its release, the Brundtland message has echoed around the world and it returns in many subsequent important publications. In the 1992 Rio Declaration, and again in the 2002 Johannesburg Declaration, the world's nations acknowledged that an exceptionally high level of consumption and nonsustainable consumer patterns in the wealthier parts of the world existed, while a large part of humankind was still withheld from the most elementary consumer needs (United Nations Conference on Environment and Development, 1992, p.8; United Nations, 2002). The tight connection and mutual relevance of social development, economic growth and environmental protection have since then been articulated in many policy and scientific publications and is regularly a key element of corporate strategies.

Before the emergence of the concept of sustainable development, social, economic and environmental issues were usually addressed in isolation. For example, policy measures aimed at environmental issues were sector-specific and $a d$ hoc. Subsequently, most companies developed ad hoc measures to mitigate the detrimental effects of their activities. Since the end of the 1980s, companies have slowly started to develop a more extroverted attitude, realising their place in a highly interconnected world. Cooperation and coordination activities with business partners and other societal stakeholders led to a more chain-focused approach. The 1990s can be considered the decade of the emergence of various forms of chain management approaches; while after the turn of the century, 
the issue of chain responsibility in relation to corporate social responsibility has been hotly debated, and the recognition of the relevance of achieving sustainability through a product chains approach is growing. Such experiences can be found in business practices and they have drawn attention in (supra)national policies and the scientific community (Bowen et al., 2001, p.41). A growing number of companies have taken the initiative in implementing practices outside their own gates aimed at reducing negative impacts associated with production and consumption activities (Sinding, 2000; de Bakker and Nijhof, 2002; Seuring and Müller, 2004). The European Union acknowledges that policies primarily focusing on large sources of pollution "need to be complemented by a policy that looks at the whole of a product's life cycle, including the use phase" (European Commission, 2003, p.3).

In practice, initiatives aiming at improving product chains' performances typically focus only on chain fragments. Scientific insight into developments regarding sustainability in full range of global product chains is lacking (Vermeulen and Ras, 2006, p.3). Furthermore, both in practice as well as in science, usually only one or sometimes two aspects of sustainable development are considered (Seuring and Müller, 2004, p.153). The result is that many opportunities for social, economic and environmental progress remain hidden and untapped.

The mentioned issues in this section raise several interesting questions from a scientific and practical point of view. We report on an exploratory research project that aimed to answer some of the most basic questions in connection to the issue of sustainability in global product chains.

In the next section, the concepts of sustainability and global product chains will be elaborated, after which a section will be dedicated to the research methodology used. In Section 3, the main results of the research will be presented. In the two sections that follow, an inventory of the barriers and opportunities of making global product chains more sustainable as perceived by the various stakeholders will be presented. In Section 6, some main conclusions will be drawn, and some important further issues will be discussed. After this, we will present some ideas regarding an agenda of progress.

\section{Sustainable global product chains}

During the 1990s, scholars from various developed countries suggested methodologies for Greening Product Chains. In theory, the Greening of Product Chains should involve the application of life cycle analysis, leading to improvement activities (Vermeulen and Ras, 2006):

- $\quad$ Producers analyse the entire life cycle of their product, identifying major environmental effects.

- They decide on objectives, either self-imposed, aiming at environmental excellence in niche markets, or applying readily available sector-wide standards (like ecolabel criteria).

- They analyse the potential levels of reduction of environmental impacts resulting from improvements in production methods, product usage and discarding the product. 
- They analyse the economics of suggested improvements and select which improvements are to be implemented.

- They implement the selected improvements within their own production facilities.

- They engage in interfirm cooperation, aiming at the implementation of identified improvements at the input side of their product's life cycles (procurement, cooperation with main suppliers, co-makerships), and at the output side (organising recycling, maintenance, information on proper use, etc.).

- They develop systems of control, preferably including third parties able to generate legitimacy.

Working along these lines, Greening of Product Chains may be expected to be the most fundamental approach in improving environmental performances of commodity chains, and it can easily be extended to the social dimension of sustainability as well, taking into account fair prices, stable employment and stable partnership relations with global suppliers (Ytterhus et al., 1999). Thus, the ultimate consequence of Corporate Social Responsibility (CSR) may very well be the adoption of Greening of Product Chains strategies. In fact, linking it to the views expressed by WCED and UNCED as discussed in the introduction, we state that a sustainable development of global product chains implies simultaneous improvement of the social, the economic and the environmental performance of activities coming from trade relations.

In another article, we discussed the state of the art in Greening of Product Chains (Vermeulen and Ras, 2006). We identified various critical issues and possible barriers companies may encounter if they embark on the route of global supply chain performance improvements:

- motivation of the initiating firm and the chain partners

- lack of required knowledge and expertise

- perception of probable costs (of knowledge generation, investments in environmental improvements, etc.) and benefits (possible cost reductions, market gains)

- power: working either in close cooperation (partnerships, coaching, co-makerships) or employing market power (selecting suppliers, threat of ceasing purchase)

- trust and continuity of supplier relations

- the role of anonymous links in the chain

- perception of consumer demand

- lack of political support

- institutional barriers in international trade.

Yet, despite these potential barriers, some entrepreneurs from various types of business have risen to the challenge of working along their product chain all the way towards suppliers in developing countries. Cases have been analysed of some such businesses and we intend to take their experiences as lessons for mainstreaming the Greening of Product Chains. This is the case for South African products exported to the Netherlands. The products selected for this purpose are exported wine and exported fruit. This led us to the following research questions: 
- What ways of working have frontrunning businesses applied for the sustainable performance of these product chains and what were the results?

- What are the perceived opportunities and barriers for further improvements amongst stakeholders, including frontrunners and mainstream at both ends of the product chains?

Moreover, we intend to use this exploratory study to lay the foundations for follow-up research to investigate the many questions that have arisen with this study.

\section{Aims and methodology}

A possible method for analysing the practices of Greening of Global Product Chains is to start from global trade relations, more specifically, the product chains connecting two nations. In order to introduce the issue of an unbalanced global economic system, one can focus on the relation between a developing and a developed nation. A typical developing-developed nation relationship is characterised by a flow of raw materials and commodities from the developing to the developed nation. In this research project, we have analysed the flow of two main products from South Africa to the Netherlands. The initial selection took place by analysing the total import value into the Netherlands. This resulted in the selection of two product groups, namely fruit and wine.

The overall import value from South Africa to the Netherlands has grown from 344 million euros in 1996 to 865 million euros in 2003. Together, fresh fruit and wine constituted around $13 \%$ of total import value in 1996. After a slight drop in 1997, this figure rose to $31 \%$ in 2000 and $35 \%$ in 2003 , which can be considered a representative value.

\subsection{Product channels and product chains}

In this study, we considered the total flow of a specific product and the related capital flows between two nations to be a product channel, while a more narrowly defined connection of linked individual firms is considered a product chain. In each of the two selected product channels, we selected two product chains with the intention to conduct interviews with chain partners at both sides of the product chain, which is both in the Netherlands and in South Africa. We knew in advance that in both product channels, some green product chains have been established in recent years, besides mainstream product chains, working according to ecolabel requirements and organic farming. In order to reach a better understanding of this, we selected one of these alternative chains in each of the product channels.

\subsection{Methodology}

Because not much research has been done in this particular field of study, we used a case study method (Eisenhardt, 1995; Yin, 2003; Koulikoff-Souviron and Harrison, 2005). As previously mentioned, we selected two product chains that connect South Africa and the Netherlands based on monetary value: the fruit and wine chains. To a large extent, the fruit and wine industries are confronted with comparable challenges and are also quite connected, as will be discussed later on. 
Within these product chains, we conducted semistructured interviews. We found interviews to be the most suitable instrument to acquire data from the various stakeholders. Owing to the unexplored character of this issue, we refrained from structuring the interviews too much. Interviewees were given as much freedom as possible to mention those aspects they considered relevant as long as they were within the scope of the research.

Besides conducting interviews, policy and corporate documents were analysed. Furthermore, various scientists active in the fields of chain management and environmental sciences were consulted. Because we conducted research within narrowly defined product chains in which most stakeholders knew each other somehow, the insights from interviews could be used to triangulate some of the acquired data (Yin, 2003).

The results we acquired cannot be generalised to any product chain owing to the used research methods. None of the analysed chains can be considered representative of the general trade relation between South Africa and the Netherlands. Another limitation, due to the semistructured interviews we conducted, is that the chains can only be compared in general terms. Also, not all relevant players in all four chains have been interviewed, making triangulation of all information impossible.

\section{Greening and the fruit channel}

In this section, we will first give an overview of some general characteristics of the fresh fruit channel connecting South Africa and the Netherlands. In the next two subsections we will specifically focus on the two selected fruit chains. In the last two subsections, we will elaborate on the perceived barriers and opportunities of greening activities within the chains. The mentioned barriers and opportunities in the fruit and wine chains partially overlap. Therefore, any barrier and opportunity already mentioned in this section will, if applicable, only be mentioned briefly in Section 5.

\subsection{General characteristics of the product channel}

In 1997, deregulation of the South African market commenced. Before that, all exports were under the control of the state. Cape Span's share in exports to Europe accounted for almost $100 \%$ in 1996 but has dropped steeply since then. Deregulation opened up the export market for all, which led to a very chaotic situation in the first years after deregulation. A great deal of inferior products from South Africa reached the world market, doing much harm to the image of South African products, including fruit and wine.

Owing to quality issues and because South Africa was only just starting to recover from the international boycotts, South African fruit only accounted for $1.7 \%$ of total Dutch fruit imports in 1996. From 1998 until 2000, this figure grew to $10.4 \%$ and since then has fluctuated between $8.9 \%$ in 2002 to $10.9 \%$ in 2003 and $8.6 \%$ in 2004 . Only Spain and Belgium (transit via the Antwerp Harbour) export more fruits to the Netherlands (CBS, 2005).

From the conventional fruit channel, we selected a table grapes chain based on talks with the industry association. We have spoken to several producers and the representing industry association, namely the South African Table Grape Industry (SATI). 


\subsection{Conventional fruits}

It was very difficult to get in touch with the largest fruit exporter in South Africa. Eventually, we only conducted interviews on the South African side of the product chain. We interviewed several grape producers - located in the Northern Province and the Northern Cape Province - and representatives of the table grape industry association. Our general findings of the interactions within the conventional grape chain are that the power balance is extremely skewed. Large export companies determine the prices producers will receive several weeks before the harvest commences. After the export company has picked up the produce, the farmers usually remain responsible for the product quality. It may then take up to several months before the farmer will be paid. Eventually, the financial compensation is often lower than initially agreed upon. Smaller producers in particular usually have no possibilities to demand higher prices, and producers do not tend to organise strongly to form a counterbalancing force although the industry is currently trying to change this situation. The industry also encountered a loss of $65 \%$ of its final produce as a surplus occurred which the market could not absorb. This further had a negative impact as $25 \%$ of the table grape producers did not have enough cash reserves and consequently lost their farms.

\subsection{Organic fruits}

We took one of the main retailers of organic fruits in the Netherlands (Eosta B.V., a company winning various prizes in the field of CSR and sustainability $)^{1}$ as our starting point of research. Via this retailer, we contacted organic fruit producers in the Western Cape and Northern Cape Provinces. These producers mainly deliver mangoes, apples and pears. The organic fruit chain turned out to be very transparent with only a few stakeholders. Besides interviews with industry stakeholders, we also had conversations with several representatives of the South African association of organic producers. The general impression of this chain is one of mutual trust. Because the market is still relatively small, the total number of players in the market is still comprehensible and there is frequent contact between chain stakeholders. The Dutch importer's managing director frequently visits his suppliers and speaks to them face to face. Also, some of the producers have visited the Netherlands to meet up with the importer and with representatives of Dutch retailers.

\subsection{Barriers}

- Lack of required knowledge and expertise

A lack of knowledge and expertise was considered an issue for all South African producers before they embarked on the endeavour to convert to organic farming. Some turned to handbooks and other international sources; some paid working visits to foreign organic producers. By and large, it was a matter of trial and error, and some of the interviewees had not expected the conversion route to be that rocky. In the conventional chain, the agricultural census as carried out by the Department of Agriculture is not considered to be all too trustworthy and complete. Adding to this, 
industry associations do not have enough and proper information about their members and their overall produce, while at the same time there is a lack of information amongst industry players about overseas market preferences.

- Perception of costs and risks

Before making the switch to organic production methods, most of the interviewees in the fruit chain had not really considered its financial implications. They felt it had to be done at any rate, so in this respect it was not perceived as a barrier. In retrospect, some of the interviewees think they might have converted too suddenly, leading to a sudden collapse of production volume as well as income. When asked why they - still a group of conventional producers - did not join forces to experiment, it became clear that nobody wanted his land to be used to experiment on. In contrast, conventional grape producers believe that improvements with regard to environmental and social issues in general cost money. Long-term gains are definitely not ruled out; but in the short term, such investments are considered very difficult, as there is a big pressure on current short-term prices.

\section{- Lack of political support}

As the South African producers were quite used to a situation in which agriculture in general does not receive financial support in terms of subsidies, they did not consider a lack of political support a barrier when thinking of switching to organic production methods. A concern that surfaced is the slow process of drawing up and passing necessary laws in this regard.

- Introduction of new nontariff barriers and Eurocentric norms

This issue arose during many of the interviews in all conventional product chains. A greening initiative could imply the introduction of new and stricter norms, which would make it even harder - especially for the smaller producers - to comply with and to keep or gain access to the world market. Furthermore, greening of the product chain is considered a Eurocentric development. Any further norms would probably be developed from a European viewpoint, therefore not giving the issues in South Africa enough consideration.

\section{- Power}

Although most producers feel that they have obtained a stronger position in the organic chain than conventional producers in their chains, the most powerful stakeholders are still considered to be on the consumer side of the chain, both in the mainstream chain and also in the organic chain. This reflects for example in the distribution costs on the European mainland and the risks of produce not being sold, which are to be (partially) borne by the South African producers. One of the producers does not agree with such distribution of the cost burden within the chain. The producer pays for distribution costs of the produce to the European retailers. In the conventional chain an unhappy producer indicated that the prices received for their produce is always lower than the agreed upon price and that it takes a long time before payment is received. 


\subsection{Opportunities}

\section{- Perception of costs and risks}

Besides a perceived barrier, this issue is also mentioned as a potential opportunity. Because market demand at this point in time is very strong, prices are favourable. Yet some of the organic producers admit that though they had switched to organic production suddenly, they strongly recommend conventional producers to convert to organic farming more gradually should they want to endeavour this opportunity.

- Workers' health

In organic production, no pesticides and herbicides are used, which in some instances can have a positive effect on working conditions and workers' health. One of the organic producers' foremen said that the working conditions had improved very much, and his people feel better in general. Besides the diminution of the direct effects of chemicals, the secondary working conditions improved as well because certain precautionary measures such as the wearing of protective masks no longer had to be taken. However, these protective measures were formerly not always used according to the prescriptions, imposing an extra risk to workers' health.

- Trust and continuity of supplier relations

At this moment, relations within the organic produce chains seem to be much more based on trust; while within the conventional chains, power play is the norm. Very illustrative of this is the fact that within the organic chain, written contracts are not always used. This strongly contrasts with the nature of the mainstream supplier, as discussed above.

\section{Greening and the wine channel}

As in Section 4, this section will first present a general overview of the wine channel connecting the Netherlands and South Africa. In the two subsections that follow, we will specifically focus on the conventional and organic wine chains within which we have conducted research. After this, the perceived barriers and opportunities of Greening of Global Product Chains will be discussed. Those aspects that were already elaborated upon in Section 4 that are also relevant for the wine channel will only be mentioned briefly.

\subsection{General characteristics of the product channel}

As in the case for fruits, the wine import value to the Netherlands has grown steadily since 1996. In the period between 2000 and 2004, the export grew 97\% (SAWIS, 2005). As with South African fruits, after the deregulation of the South African market in the mid-1990s, the quality of some South African wines was debatable, and the overseas image was not very good. 
A great effort has been made to improve this image; the industry initiated an Integrated Production of Wine (IPW) scheme, which was put into effect in 1998. That same year, the South African Wine and Spirit Board started quality checks. South African wine quality has improved since then, which is reflected in export figures.

The growth of exports to all overseas markets is strong. As of 2004, the Netherlands was the second largest buyer. It has been the only country in which the growth of imports of South African wine has slightly stalled ${ }^{2}$ (in 2004), as there is fierce competition from other New World wine nations (i.e., Chile, Argentina, Australia and California). The Old World nations, notably France, are facing a steady decline in their market share (down from more than 50\% in the 1990s to around 44\% in 2004 (CBS, 2005)).

In Dutch shops such as supermarkets and liquor stores, organic wines have a very small market share; estimations show a figure below 1\% (Biologica, 2004), but retailers have started to pay some attention to this issue. Selling environmentally sound wine mainly started as a result of a voluntary agreement in the retail sector to raise the share of consumer expenditures on organically produced food products to $5 \%$ in $2005 .^{3}$ Also, some very small businesses started to sell wine with the EKO-label through 'greenshops' and the internet.

Looking at the South African side of the wine channel, various activities have been deployed with respect to greening activities and other social and ethical issues. In the 1990s, the South African wine industry initiated the Integrated Production of Wine (IPW) scheme, aimed at improving the product's quality and, as a result, the image of South African wines abroad. Initially, IPW specifically aimed at environmental and managerial aspects (such as introducing environmental management systems). At this moment there are ongoing discussions to broaden IPW's scope to the social dimension of wine production as well. In addition, in 2004 the implementation of the Wine Biodiversity Initiative commenced with the aim to conserve the unique floristic features of the Western Cape Floristic Region - the smallest but at the same time one of the richest global Floristic ecosystems (Fairbanks et al., 2004). Nongovernmental parties and the industry have made initial funds available. From 2006, this initiative will be completely funded by the wine industry.

Moreover, in 2002, the Wine Ethical Trade Association (WIETA) was established. Industry (wine producers, retailers), trade unions, government and nongovernmental organisations have joined this initiative and together promote ethical trade practices.

\subsection{Conventional wine chain}

We began with one of the main Dutch retailers, TSN Schuitema B.V., with a domestic market share of around $17 \%$. Some years ago, the retailer realised that the share of South African wines in its assortment was insufficient, and since 2004, the retailer has started to do business with a South African wine producer from the Northern Cape. This supplier accounts for more than $20 \%$ of the total South African wine production. Within this chain, we conducted interviews with the product chain manager from the Dutch retailer, senior managers from the South African wine producer, wine grapes producers and industry associations (Wines of South Africa and IPW). According to the TSN Schuitema B.V. representative, one of the best assets of Orange River Wine Cellar is its responsiveness. He found that in many other countries where TSN Schuitema B.V. sources its wines, the service level is not as up to scratch as is the case with Orange River 
Wine Cellar. The TSN Schuitema B.V. representative illustrated this with a situation in which Orange River Wine Cellar was sending tasting samples to TSN Schuitema B.V. Suggested changes were immediately carried out by Orange River Wine Cellar to meet demands and retain market share.

\subsection{Organic wine chain}

Currently, there are no official European rules that define 'organic wine'. Certifying organisations however, have already developed norms, anticipating the future European policy. At present, 'organic wines' are either wines that have been produced according to these unofficial norms or wines that have been made from organic grapes (for which there are official rules in place). For the sake of simplicity, in this stage we refer to both types of wines as 'organic wines'.

Within the organic wine chain, we conducted interviews with an organic wine producer from the Western Cape (Namaqualand). We also interviewed the chairman of an organisation representing producers of organic products in South Africa. Their wines are imported into the Netherlands by a small importer.

\subsection{Barriers}

The following list is an overview of the barriers as perceived by the stakeholders within the conventional and organic wine chain. Where applicable, the issues point back to the greening of global product chains theory from Section 2. As previously mentioned, some barriers and opportunities have been omitted and can be found in the fruit section, because stakeholders in the fruit chain mentioned these with more emphasis.

- Motivation and perception of need

Most interviewees, both on the South African as well as on the Dutch side of the conventional chain, found complying with the ruling laws and wishes of buyers sufficient and did not see any need to go any further. However, it is acknowledged that one has to anticipate world demand and should be able to fulfil changing consumer preferences. If needed, on the production side, a switch to organic production, for example, would be possible. Northern Cape stakeholders have always had to operate in very specific, often harsh, physical circumstances. Therefore, it is claimed, for generations they have always had to be very considerate towards nature. One grape producer stated that he could very well be persuaded to implement cleaner production methods, but only if the advantages for the environment would be completely unambiguous.

- Knowledge and expertise

At this stage, there is a serious lack of proper industry information. The agricultural census carried out by the Department of Agriculture is not considered to be all too trustworthy and complete. Also, industry associations do not have enough and proper information about their members and their overall produce; while at the same time there is a lack of information amongst industry players about overseas market preferences. Some of the South African interviewees indicated that there is a lack of 
research into production methods and environmental effects of grape production and wine-making in the Northern Cape region. This is applicable in both the organic and conventional chains.

- Lack of policy support

As opposed to the Netherlands and the European Union, there is no special policy support for organic production in South Africa at all. A stakeholder within the conventional wine chain mentioned that organic production is only one way to improve the chain's environmental performance. In his view, policy aimed at stimulating organic production could have a discriminatory effect against the conventional industry, which partly strives to improve product chain performance in another way.

- Costs

One of the conventional grape producers believes that improvements with regard to environmental and social issues in general cost money. Long-term gains are definitely not ruled out; but in the short term, such investments are considered very difficult, as there is a huge pressure on current short-term prices. On the one hand, improving the chain's efficiency and lowering overall cost could mean that, for example, bottling and labelling activities occur on the Dutch side of the chain. Also, from an environmental point of view, it could be that energy use is lowered when bottling occurs on the Dutch side of the chain. However, this will lead to fewer value-added activities on the South African side of the chain and it would not add to addressing the priority social issue of employment. As one of the interviewees said: "You employ people by letting them do the labelling."

\section{- Power}

According to one of the interviewees, the power of overseas retailers is underestimated. Because of their strong power position, these retailers dictate prices to a large extent. Deploying production-side improvement activities may turn out to be difficult as margins are small. The interviewed producer of conventional grapes mentioned the domination of prices, assortment and production techniques by the exporting company.

- Trust and continuity of supplier relations

Within the wine chain, this factor is of great importance. On the one hand, TSN Schuitema B.V. gives a lot of importance to good chain relations because it needs a continuous supply of high volumes of wine which has a favourable price/quality ratio. By analysing the logistical side of product chains and good chain cooperation, some improvements have been realised. For example, it turned out that the wine containers were not always stacked on the lower decks of the boats, although this has always been Orange River Wine Cellar's request. Unless you get a written declaration, you cannot be sure about this. Even the experienced forwarding company who had been shipping wine for 18 years did not know this. Thus, keeping in close contact with all chain stakeholders enables one to identify and solve (sometimes seemingly trivial) issues, and build trust. In the organic chain, trust is a norm that exists and is respected, while on the other hand the conventional chain is not embedded in trust as a given norm in business practices. 


\section{- Institutional barriers in international trade}

One of the interviewees said that the problem particularly lies on the European side of the chain: "Europe wants to protect itself". However, on the South African side, the chains' stakeholders also mentioned some issues. Both stakeholders on the South African and Dutch sides criticise the SA Wine and Spirits Board procedures for acquiring export clearances. Samples of the wine designated for export have to be sent in for tasting by the Stellenbosch-based panel. This is a procedure that is time consuming with not much consistency.

- Improvement of social circumstances versus maintaining jobs

Orange River Wine Cellar strives for phasing out suboptimal working conditions and wants to improve production efficiency (and reduce costs) through automating certain production phases. However, this might lead to the diminishing of jobs. Wherever possible, manual labour is maintained because Orange River Wine Cellar sees it as a major social responsibility to provide for jobs to the local communities.

\subsection{Opportunities}

- Uplifting poor individuals and communities

Because organic agricultural production is usually more labour intensive than conventional production, it is seen as a possible way of providing more employment opportunities to the communities. However, to be able to finance more labour, margins have to be higher than in conventional production.

- Consumer demand

Although it has also been placed in the list of 'barriers', according to some, consumer demand is an opportunity. Consumer demand in Western Europe for organically produced products is growing fast: in some cases, more than $20 \%$ per annum and in the case of this particular wine maker more than $100 \%$ per annum. Larger producers especially experience this as a barrier, whilst smaller companies tend to see the opportunities it creates.

- Power

Because demand for organic products is currently very strong, producers have a relatively strong bargaining position. This gives them the opportunity to reduce the risk they have to bear throughout the chain and receive better prices for their products.

\section{Conclusions and discussions}

Some important conclusions can be drawn from the aforementioned barriers and opportunities. After discussing these, we will elaborate on some of the most prominent discussions, after which we will shed some light on an agenda for scientific, environmental and socioeconomic progress. 
This exploratory study has shown that many stakeholders have already initiated or joined initiatives to green their product chain. However, we have also seen that greening is only one aspect of sustainable global product chain performance. Besides an improvement in the environmental performance of the product chains, initiatives to improve the social and economic performance have also been identified. Within both the grape and wine industries, voices are calling upon all industry stakeholders to pay attention in an integrated way to economic, social and environmental aspects.

South African stakeholders know very well what the most important issues related to food quality and the environment are. Dutch and other European retailers impose certain standards such as Eurep-GAP, Hazard Analysis and Critical Control Point (HACCP) and British Retail Consortium (BRC) on their suppliers. In the case of organic production, EU organic food guidelines are used. Within the conventional chain, Dutch retailers do keep an eye on social issues but not according to any specific guidelines. In general, in the conventional chains, chain responsibility de facto means imposing certain standards on suppliers. Dutch stakeholders have not initiated many activities to actually assess the main issues that South African stakeholders consider the most prominent challenges. Within the organic fruit and wine chains, much more attention is given to location-specific challenges.

Within the conventional fruit chain, the willingness to join forces seems to be small. The issue arose in several interviews and the defensive attitude of smaller farmers has been frequently mentioned as an important cause. One example of this is the unwillingness of a group of smaller grape producers to join forces and experiment with organic production because no one was willing to volunteer his land to be experimented upon. The table-grape industry association clearly strives for more cooperation, both domestically as well with producers from South America. A shift can be seen from mistrusting other producers to joining forces as an industry to improve product quality and production efficiency, but also to counterbalance the sheer dominance of European retailers.

South African parties have declared themselves very open to tighter cooperation for better product quality control, the improvement of social circumstances, reduction of environmental impacts and the improvement of the chain's ability to compete. However, they also mentioned that in future discussions on the sustainability of global product chains, the European agenda should be a little less dominant.

\subsection{Ongoing points of discussion}

- Sustainability: what does it mean?

Perceptions regarding product chain performance and sustainability in South Africa and the Netherlands show an interesting distinction. When asked about the main issues in global product chains, the Dutch stakeholders stress the importance of product quality and its related issues. South African stakeholders concur on the importance of quality issues, as the global market demands high-quality products. However, they state that other issues such as poverty, unemployment and HIV/AIDS are very important as well. From a South African point of view, the perceived barriers and opportunities differ from those from a Dutch point of view. 
- Chain responsibility: inclusive and opportunistic

Amongst European policymakers and companies, the concept of chain responsibility has become a very widespread philosophy. During this research, two quite different ways of interpreting this concept have arisen. One can distinguish an ideal and an opportunistic interpretation.

\section{- Inclusive chain responsibility}

As mentioned in the introduction, an essential part of sustainable development is the gradual phasing out of inequality in global economic exchanges. This will enable developing countries to profit from their competitive strength on the global market. Furthermore, it is the nations' challenge to uplift the poorest and enable them to build lives worthy of human beings. Hardly anyone can deny that a great task for the global community lies ahead and that developed nations have a distinguished task therein. After Brundtland, this thought was clearly articulated at the 1992 Rio UNCED Conference and again at the 2002 Johannesburg World Summit. Recalling the essence of the Rio Declaration as mentioned in Section 2, chain responsibility would mean that developed nations' stakeholders would take responsibility for their consumer and investment decisions. Ultimately, besides the positive effects of buying products from the developed world, one should also consider the detrimental effects and act accordingly. Concretely, this would mean that developed nations' stakeholders would accept joint responsibility for addressing the challenges of those in the developing world. In the case of South African agricultural communities, this could mean helping to raise educational standards and environmental awareness and addressing the HIV/AIDS issue, which is an increasing problem in rural areas.

- Opportunistic chain responsibility

However, in practice, various stakeholders in Europe interpret chain responsibility very differently. A widespread practice is to take the issues that European stakeholders find interesting and most important. The topics that drive policy and practice in Europe are those concerning food safety, product price and quality, and the environment. The European consumer demands healthy and high-quality products for a reasonable price. European retailers and governments respond to this by demanding that producers apply high standards. Many companies have started to take responsibility for these issues throughout the product chains and call these practices 'chain responsibility'. The result is indeed better, safer, more environment-friendly products for reasonable prices. But what has actually happened on the production side of the chains? Take the South African conventional table grape industry as an example. The exporter has confronted many conventional producers with higher demands, because world market demand for higher quality products is on the rise. Producers have no choice but to adhere to these demands if they want to remain active in delivering fresh produce to the world market. The problems and challenges these producers face are slim margins, price uncertainty, exceptionally high risks, inability to afford better wages and black economic empowerment. In coping with these challenges, actual assistance from upstream stakeholders is limited. For these reasons, and owing to fierce competition from 
other grape-producing nations, the South African table grape industry has been faced with some losses: in 2004, the average loss per box of grapes was about 12 rand, which equals about 1.5 euro (Moodley, 2006).

\subsection{How to proceed?}

This research project shows the need for more discussions of sustainable development between chain stakeholders, both on the South African as well as the Dutch side, or broader, between the Northern and Southern Hemisphere nations. Furthermore, there is an obvious gap between the more scientific, 'all-inclusive' approach and the daily practice regarding product chain performance and cooperation.

To bridge these gaps, it is important that both South African as well as Dutch industry stakeholders intensify discussions and start to identify the opportunities of an integrated approach aimed at making the chains in which they are involved more sustainable, from a social, economic and environmental point of view.

Secondly, industry stakeholders and scientific parties should increase collaboration. Science can deliver methods for chain stakeholders to engage in fruitful discussions and to initiate a process of change, while the industry can provide valuable access to trustworthy case study objects for scientific parties.

Thirdly, nongovernmental and various governmental stakeholders have important roles to play. The government can break down institutional barriers and provide a framework within which others can strive for progress, while nongovernmental organisations can represent stakeholders that otherwise would barely be heard.

Ergo, we call for extensive collaboration between all societal stakeholders in global product chains with the aim to make these chains more sustainable. There is a high potential of improving global product chain performance in all three mentioned dimensions of sustainability. We have identified the need and the desire and have seen some good examples of such sustainability. All that remains is to make it happen.

\section{References}

Biologica (2004) EKO Monitor, cijfer en tends, jaarrapport, Utrecht.

Bowen, F.E., Cousins, P.D., et al. (2001) 'Horses for courses: explaining the gap between the theory and practice of green supply', Greener Management International, Vol. 35, pp.41-60.

CBS (2005) STATLINE, http://statline.cbs.nl/StatWeb/ (retrieved 16 May 2005).

De Bakker, F. and Nijhof, A. (2002) 'Responsible chain management: a capability assessment framework', Business Strategy and the Environment, Vol. 11, No. 1, pp.63-75.

Eisenhardt, K.M. (1995) 'Building theories from case study research', in G.P. Huber and A.H.v.d. Ven (Eds.) Longitudinal Field Research Methods, Sage: Thousand Oaks, pp.65-90.

European Commission (2003) 'Integrated product policy', Building on Environmental Life-Cycle Thinking, Brussels.

Fairbanks, D.H.K., Hughes, C.J., et al. (2004) 'Potential impact of viticulture expansion on habitat types in the Cape Floristic Region, South Africa', Biodiversity and Conservation, Vol. 13, pp.1075-1100.

Koulikoff-Souviron, M. and Harrison, A. (2005) 'Using case study methodology in supply chain integration research', in H. Kotlab, S. Seuring, M. Müller and G. Reiner (Eds.) Research Methodologies in Supply Chain Management, Heidelberg: Physica Verlag, pp.267-282. 
Moodley, N. (2006) 'Annus horriblis for table grape sector', Business Report.

SAWIS (2005) Annual South African Wine Industry Statistics, Paarl, South African Wine Industry Information Systems.

Seuring, S. and Müller, M. (2004) 'Beschaffungsmanagement \& Nachhaltigkeit - eine Literaturübersicht', in M. Hülsmann, G. Müller-Christ and H.D. Haasis (Eds.) Betriebswirtschaftslehre und Nachhältigkeit - Bestandsaufnahme und Forschungsprogrammatik, Wiesbaden: Gabler Verlag, pp.117-170.

Sinding, K. (2000) 'Environmental management beyond the boundaries of the firm: definitions and constraints', Business Strategy and the Environment, Vol. 9, No. 2, pp.79-91.

United Nations (2002) Report of the World Summit on Sustainable Development Johannesburg, New York, United Nations.

United Nations Conference on Environment and Development (1992) Agenda 21, Rio Declaration, New York, United Nations.

Vermeulen, W.J.V. and Ras, P. (2006) 'The challenge of greening global product chains: meeting both ends', Sustainable Development, Vol. 14, No. 4, pp.245-256.

WCED (1987) Our Common Future, Oxford: Oxford University Press.

Yin, R.K. (2003) Case Study Research: Design and Methods, Beverly Hills.

Ytterhus, B.E., Arnestad, P., et al. (1999) 'Environmental initiatives in the retailing sector: an analysis of supply chain pressures and partnerships', Eco-Management and Auditing, Vol. 6, No. 4, pp.181-188.

\section{Notes}

www.eosta.com

2 Interview with S. Birch (Wines of South Africa), Stellenbosch (South Africa), 22 April 2005.

3 This target will not be met. A new target of 5\% has been set for 2007 . 